\title{
Methane production and energy partition of cattle in the tropics
}

\author{
M. Kurihara*, T. Magner, R. A. Hunter and G. J. McCrabb $\dagger$ \\ CSIRO Tropical Agriculture, Tropical Beef Centre, Rockhampton, Queensland 4702, Australia
}

(Received 7 May 1998 - Revised 24 August 1998 - Accepted 26 October 1998)

\begin{abstract}
The aim of this experiment was to determine $\mathrm{CH}_{4}$ production and energy partition for a range of diets fed to Bos indicus cattle. Six Brahman cattle were fed on three different diets in a replicated Latin square experiment over three periods. The diets were (1) long-chopped Angleton grass (Dicanthium aristatum) hay ad libitum (DM digestibility (DMD) 41 (SE 2) \%; 4 g N/kg), (2) longchopped Rhodes grass (Chloris gayana) hay ad libitum (DMD 60 (SE 1) \%; $14 \mathrm{~g} \mathrm{~N} / \mathrm{kg}$ ) or (3) $2 \mathrm{~kg}$ long-chopped lucerne (Medicago sativa) hay/d plus a high-grain diet (ad libitum) (DMD 70 (SE 1) $\% ; 31 \mathrm{~g} \mathrm{~N} / \mathrm{kg}$ ). $\mathrm{CH}_{4}$ production was measured using confinement-type respiration chambers. Metabolizable energy intake (MJ/d) of cattle fed on Angleton grass (18.4 (SE 2.0)) was lower ( $P$ $<0.01)$ than that for Rhodes grass $(54.9$ (SE 2.1)), which was lower $(P<0 \cdot 01)$ than that for the high-grain diet (76.7 (SE 5.8)). $\mathrm{CH}_{4}$ production (g/d) for cattle fed on Rhodes grass (257 (SE 14)) was higher $(P<0.01)$ than that for cattle fed on both the high-grain diet (160 (SE 24)) and Angleton grass (113 (SE 16)) $\mathrm{CH}_{4}$ conversion rate $\left(\mathrm{MJ} \mathrm{CH}_{4}\right.$ produced per $100 \mathrm{MJ}$ gross energy intake) was not significantly different between cattle fed on Angleton (10.4 (SE 1.1)) and Rhodes $(11.4(\mathrm{SE} 0.3))$ grass, but was higher $(P<0.01)$ than for cattle fed on the high-grain diet (6.7 (SE $0 \cdot 7)$ ). $\mathrm{CH}_{4}$ production $(\mathrm{g} / \mathrm{kg}$ live-weight gain) was associated $(P<0 \cdot 001)$ with both live-weight gain and feed: gain ratio. We conclude that the relationships between $\mathrm{CH}_{4}$ production, energy utilization and live-weight change of cattle fed on tropical forages differ from those of cattle fed on diets based on temperate forages.
\end{abstract}

Ruminant: Methane production: Tropical forage diet

$\mathrm{CH}_{4}$ is produced by micro-organisms in the rumen of ruminant livestock (cattle, buffalo, sheep, goats) during anaerobic fermentation of the soluble and structural carbohydrates contained in forage-based diets. $\mathrm{CH}_{4}$ is considered a 'greenhouse gas' and emissions of the global cattle population of 1.3 billion are estimated to be 58 million tonnes/year, or $73 \%$ of the emissions from all livestock species (US Environmental Protection Agency, 1994). Estimates of $\mathrm{CH}_{4}$ production by cattle used in both international publications (Crutzen et al. 1986; US Environmental Protection Agency, 1994; Intergovernmental Panel on Climate Change, 1990) and the Australian greenhouse gas inventory (National Greenhouse Gas Inventory Committee, 1996) for live-stock are based on data collected from British breeds of cattle (Bos taurus) and sheep fed on temperate forage-based diets (Blaxter \& Clapperton, 1965), and Holstein cows fed on concentrate diets (Moe \& Tyrrell, 1979). The inventory of $\mathrm{CH}_{4}$ emissions from cattle in Japan is based on data from B. taurus (Japanese Black and Holstein) cattle, sheep and goats fed on diets based on temperate forages and cereal grains (Shibata et al. 1993). $\mathrm{CH}_{4}$ production by cattle typically accounts for $5 \cdot 5-6.5 \%$ of gross energy (GE) intake (Johnson \& Ward, 1996), however values of 2$12 \%$ (Czerkawski, 1969) have been reported on some diets. At least $50 \%$ of the global cattle population is located in developing countries, many of which are in tropical regions of the world (US Environmental Protection Agency, 1994). Reviews of the literature by the US Environmental Protection Agency (1994) and National Greenhouse Gas Inventory Committee (1996) have drawn attention to the lack of data describing $\mathrm{CH}_{4}$ production and energy utilization of tropical breeds of cattle fed on tropical forage diets. Therefore, the objective of the present experiment was to determine $\mathrm{CH}_{4}$ production and energy partition for a range of diets that represent those fed to cattle (B. indicus) in the tropical regions of the world.

\section{Materials and methods}

Animals and their management

Six Brahman (B. indicus) heifers, aged 3.5 years and initially weighing $300-350 \mathrm{~kg}$, were housed in individual

\footnotetext{
Abbreviations: ADF, acid-detergent fibre; GE, gross energy; MCR, methane conversion rate; NDF, neutral-detergent fibre.

* On leave from: Department of Animal Nutrition, National Institute of Animal Industry, Tsukuba, Ibaraki 305, Japan.

$\dagger$ Corresponding author: Dr Graeme McCrabb, fax + 6174923 8222, email graeme.mccrabb@tag.csiro.au
} 
pens in a roofed animal house. Before the experiment began heifers underwent a training programme which involved restraining them with halters and yokes, and housing them in respiration chambers and metabolism cages. This training programme ensured that the heifers maintained uniform patterns of feed intake during the subsequent experimental measurements. After this training period the animals were weighed and allocated to three pairs which were used in a replicated Latin square experiment conducted over three periods. During each period two heifers were fed on each of three different diets; the diets were selected to represent some of those fed to cattle in tropical regions of the world including northern Australia. The experimental diets were (1) mature Angleton grass (Dicanthium aristatum) hay provided ad libitum, (2) immature Rhodes grass (Chloris gayana) hay provided ad libitum and (3) $2 \mathrm{~kg}$ lucerne (Medicago sativa) hay/d plus a high-grain diet provided ad libitum. All hay diets were long-chopped before being offered to cattle. The high-grain diet was a commercially prepared diet based on sorghum $(570 \mathrm{~g} / \mathrm{kg})$, barley $(100 \mathrm{~g} / \mathrm{kg})$ and wheat $(100 \mathrm{~g} / \mathrm{kg})$. Table 1 presents the chemical composition of the diets used in this experiment. Feed was offered daily at 08.00 hours, and ad libitum intake was ensured by providing sufficient feed such that $0.5-$ $1.5 \mathrm{~kg}$ of the feed remained uneaten $24 \mathrm{~h}$ later. Fresh drinking water was available at all times. Live weight was measured immediately before feeding, at weekly intervals throughout the experiment.

Each period of the experiment was $42 \mathrm{~d}$ in duration. Initially, heifers were fed on the allocated diet for $28 \mathrm{~d}$ before measurements of $\mathrm{CH}_{4}$ production and energy partition. During days 22-28, pattern of feed intake was measured by manual weighing at 12.00 and 16.00 hours on $2 \mathrm{~d}$ in pens and $1 \mathrm{~d}$ in the respiration chambers in order to confirm that intake pattern of cattle in the respiration chambers was similar to intake pattern in the pens. On days 29,31 and 33 $\mathrm{CH}_{4}$ production, $\mathrm{O}_{2}$ consumption and $\mathrm{CO}_{2}$ production were measured, as described later, over a $24 \mathrm{~h}$ period using two confinement-type respiration chambers (two cattle/d). These respiration chamber measurements were randomized for experimental diet. On day 35 all heifers were transferred to metabolic cages for $8 \mathrm{~d}$. Faeces and urine output were measured over 7 d (i.e. days 36-42). Faeces were collected in bins placed at the rear of the metabolic cage. Urine was collected into acid $(\mathrm{HCl})$, in order to maintain urine $\mathrm{pH}$ between 3 and 4 units, using vinyl bags fixed over the heifer's vulva (Magner et al. 1988).

\section{Respiration chamber}

Two confinement-type respiration chambers, similar to those described by Turner \& Thornton (1966), were used to measure $\mathrm{CH}_{4}$ production, $\mathrm{O}_{2}$ consumption and $\mathrm{CO}_{2}$ production over a $24 \mathrm{~h}$ period. During the measurement period the respiration chambers were maintained at $27^{\circ}$ and $40 \%$ relative humidity, which is the thermoneutral zone for cattle adapted to a tropical environment. On the day of measurement thirty-two to thirty-six individual measurement runs were conducted, each $24-36 \mathrm{~min}$ in duration. Each measurement run was followed by a period of time (6-12 min) sufficient to ensure that concentrations of $\mathrm{O}_{2}$, $\mathrm{CO}_{2}$ and $\mathrm{CH}_{4}$ in the chamber had returned to basal concentrations. During each measurement run, air was continuously sampled from the chamber and analysed for concentrations of $\mathrm{CH}_{4}$ (Beckman, Model no. 875; Beckman Instruments Inc., Fullerton, $\mathrm{CA}$, USA) and $\mathrm{CO}_{2}$ (Beckman, Model no. 864) using infrared analysers, and for $\mathrm{O}_{2}$ with a paramagnetic analyser (Beckman, Model no. 755). Gas analysers were calibrated against certified gases (CIG, Chatswood, NSW, Australia) with known gas concentrations at the beginning of each measurement day. The rates of gas exchange $(\mathrm{ml} / \mathrm{min})$ at standard temperature $\left(0^{\circ}\right)$ and pressure $(760 \mathrm{mmHg})$ were calculated from the change in individual gas volumes in the chamber over time.

\section{Feed digestibility}

Heifers were housed in metabolic cages to enable simultaneous measurements of feed intake, and faecal and urinary output over $7 \mathrm{~d}$. Each day a sub-sample of the feed offered was collected; these were combined and stored under ambient conditions for later analysis. Daily refusals of feed, and output of faeces and urine were also measured and sub-samples $(100 \mathrm{~g} / \mathrm{kg})$ collected. Feed refusals were dried in an oven at $50^{\circ}$ for $48-72 \mathrm{~h}$. Faecal and urine samples were stored at $-5^{\circ}$, and at the completion of the collection period a sub-sample was freezedried for analysis.

Table 1. Chemical composition of diets

\begin{tabular}{lcccc}
\hline & & & & High grain \\
\cline { 4 - 5 } & Angleton grass & Rhodes grass & Lucerne & Grain component \\
\hline Dry matter $(\mathrm{g} / \mathrm{kg})$ & 899 & 877 & 891 & 878 \\
Organic matter (g/kg DM) & 879 & 894 & 881 & 924 \\
Acid-detergent fibre (g/kg DM) & 458 & 353 & 277 & 59 \\
Neutral-detergent fibre (g/kg DM) & 753 & 718 & 408 & 122 \\
Cellulose (g/kg DM) & 394 & 314 & 221 & 44 \\
Hemicellulose (g/kg DM) & 296 & 366 & 131 & 14 \\
Lignin (g/kg DM) & 64 & 38 & 56 & 614 \\
Non-fibre carbohydrate (g/kg DM) & 92 & 66 & 185 & 171 \\
Crude protein (g/kg DM) & 24 & 89 & 269 & 19 \\
Ether extract (g/kg DM) & 10 & 21 & 19 & 17.45 \\
Gross energy (MJ/kg DM) & 16.67 & 17.47 & 18.55 & \\
\hline
\end{tabular}




\section{Chemical analysis}

Feed, feed refusals and faecal samples were ground through a $1 \mathrm{~mm}$ screen in preparation for chemical analysis. Urine was freeze-dried and manually crushed for subsequent chemical analysis. Heat of combustion was determined using an adiabatic bomb calorimeter, total $\mathrm{N}$ content after Kjeldahl digestion using the method of Williams \& Twine (1967), and DM content by drying in an oven at $100^{\circ}$ for $48 \mathrm{~h}$. Chemical determinations of organic matter, ash, aciddetergent fibre (ADF), lignin and ether extract were conducted on feed, feed refusals and faeces using standard methods reviewed by Faichney \& White (1983). Neutraldetergent fibre (NDF) was analysed using the procedures of Van Soest et al. (1991). From these values, crude protein $(\mathrm{N} \times 6 \cdot 25)$, hemicellulose (NDF minus ADF), cellulose (ADF minus lignin) and non-fibre carbohydrate (organic matter-(NDF + crude protein + ether extract)) contents of feed, feed refusals and faeces were calculated.

\section{Energy balance}

The energy values of samples of feed, feed refusals and excreta collected from the $7 \mathrm{~d}$ digestibility measurement were used to calculate energy balance. GE intake was determined using the values for heat of combustion of feed and feed refusal. Digestible energy intake was calculated as the difference between GE intake and faecal energy output. Metabolizable energy (ME) intake was determined as the difference between digestible energy intake, and urinary and $\mathrm{CH}_{4}$ energy output. $\mathrm{CH}_{4}$ gas volume was converted to energy and mass values using the conversion factors $39.54 \mathrm{~kJ} / \mathrm{l}$ and $0.716 \mathrm{~g} / \mathrm{l}$ respectively (Brouwer, 1965). Heat production $(\mathrm{kJ} / \mathrm{d})$ was calculated using the equation: $16 \cdot 18 \mathrm{O}_{2}$ (litres/d) +5.02 $\mathrm{CO}_{2}$ (litres/d) - 2.17 $\mathrm{CH}_{4}$ (litres/d) - 5.99 N (g/d) (Brouwer, 1965). Energy retention (MJ/d) was calculated using the equation: $\mathrm{ME}$ - heat production.

\section{Calculations and statistical analysis}

Live-weight change was calculated by linear regression analysis of measurements of live weight made from 2 weeks after the beginning of each experimental period, thus avoiding any effect of gut fill during adaptation to each new diet. Average hourly rates of $\mathrm{CH}_{4}$ production were determined by calculating the mean rate of $\mathrm{CH}_{4}$ production for all available measurements during each successive hour. Data were analysed by ANOVA with dietary treatment and period as factors (Statistical Analysis Systems, version 6.12; SAS Institute Inc., Cary, NC, USA). The significance of the difference between individual group means was determined using a Tukey's studentized range test. Data are presented as means and pooled standard errors of the mean.

\section{Results}

\section{Diet composition and digestibility}

Of the three experimental diets, Angleton grass had the lowest crude protein content and the highest ADF, NDF and cellulose contents (Table 1). The high-grain diet had the highest crude protein content and lowest ADF, NDF, cellulose and hemicellulose contents. The chemical composition of the Rhodes grass was intermediate between Angleton grass and the high-grain diet. The apparent digestibilities of DM, organic matter, and GE were lowest for the Angleton grass and highest for the high-grain diet, whereas the apparent digestibilities of ADF, NDF, cellulose and hemicellulose were highest for the Rhodes grass (Table 2).

\section{DM intake and live-weight change}

Voluntary DM and organic matter intakes $(\mathrm{kg} / \mathrm{d})$ for cattle fed on Rhodes grass and the high-grain diet were higher $(P<0.001)$ than for cattle fed on Angleton grass (Table 3). DM intakes $(\mathrm{kg} / \mathrm{d})$ of cattle on the day of measurement in respiration chambers (Rhodes, 6.7 (SE 0.3); Angleton, 3.6 (SE 0.4); high grain, 7.9 (SE 0.6)) were not significantly different to DM intakes during the $7 \mathrm{~d}$ collection period when cattle were housed in metabolic cages (Rhodes, 7.1 (SE 0.3); Angleton, 3.6 (SE 0.3); high grain, 7.3 (SE 0.6)). Rate of live-weight gain $(\mathrm{kg} / \mathrm{d})$ for cattle fed on the highgrain diet was higher $(P<0.01)$ than for cattle fed on Rhodes grass, whereas cattle fed on Angleton grass experienced live-weight loss (Table 3).

\section{Energy partition}

GE intake and digestible energy intake of cattle fed on Angleton grass were lower $(P<0 \cdot 001)$ than for cattle fed on Rhodes grass and the high-grain diet (Table 3$)$. ME intake

Table 2. Apparent digestibility of diets*

(Mean values with their pooled standard errors)

\begin{tabular}{|c|c|c|c|c|c|}
\hline & $\begin{array}{l}\text { Angleton grass } \\
\qquad(n 6)\end{array}$ & $\begin{array}{l}\text { Rhodes grass } \\
\quad(n 6)\end{array}$ & $\begin{array}{l}\text { High grain } \\
\qquad(n 6)\end{array}$ & Pooled SE & $\begin{array}{l}\text { Statistical significance of } \\
\text { difference between means }\end{array}$ \\
\hline Dry matter & $0.413^{\mathrm{a}}$ & $0.603^{b}$ & $0.697^{c}$ & 0.016 & $P<0.01$ \\
\hline Organic matter & $0.467^{a}$ & $0.626^{\mathrm{b}}$ & $0.731^{\mathrm{c}}$ & 0.018 & $P<0.01$ \\
\hline Neutral-detergent fibre & $0.547^{a}$ & $0.688^{b}$ & $0.532^{a}$ & 0.024 & $P<0.01$ \\
\hline Cellulose & $0.615^{\mathrm{a}}$ & $0.735^{\mathrm{b}}$ & $0.590^{\mathrm{a}}$ & 0.021 & $P<0.01$ \\
\hline Hemicellulose & $0.547^{a}$ & $0.715^{\mathrm{b}}$ & $0.643^{a b}$ & 0.035 & $P<0.05$ \\
\hline
\end{tabular}

a,b,c Mean values within a row not sharing a common superscript letter were significantly different, $P<0.05$.

* For details of diets, see Table 1. 
Table 3. Live weight, feed intake and energy partition of cattle fed on Angleton grass, Rhodes grass or a high-grain diet (Mean values with their pooled standard errors)

\begin{tabular}{|c|c|c|c|c|c|}
\hline & $\begin{array}{l}\text { Angleton grass } \\
\qquad(n 6)\end{array}$ & $\begin{array}{l}\text { Rhodes grass } \\
\qquad(n 6)\end{array}$ & $\begin{array}{l}\text { High grain } \\
\qquad(n 6)\end{array}$ & Pooled SE & $\begin{array}{l}\text { Statistical significance of } \\
\text { difference between means }\end{array}$ \\
\hline Live weight $(\mathrm{kg})$ & 353 & 364 & 380 & 8 & NS \\
\hline Change in live weight $(\mathrm{kg} / \mathrm{d})$ & $-0.88^{a}$ & $0.57^{b}$ & $1 \cdot 30^{\mathrm{c}}$ & 0.16 & $P<0.05$ \\
\hline Dry matter $(\mathrm{kg} / \mathrm{d})$ & $3.58^{a}$ & $7 \cdot 07^{b}$ & $7 \cdot 31^{b}$ & 0.40 & $P<0.001$ \\
\hline Organic matter $(\mathrm{kg} / \mathrm{d})$ & $3 \cdot 1^{\mathrm{a}}$ & $6 \cdot 3^{\mathrm{b}}$ & $6 \cdot 7^{\mathrm{b}}$ & 0.4 & $P<0.001$ \\
\hline Acid-detergent fibre $(\mathrm{kg} / \mathrm{d})$ & $1.6^{a}$ & $2 \cdot 5^{b}$ & $0.8^{\mathrm{c}}$ & 0.1 & $P<0.001$ \\
\hline Neutral-detergent fibre $(\mathrm{kg} / \mathrm{d})$ & $2 \cdot 7^{\mathrm{a}}$ & $5 \cdot 1^{\mathrm{b}}$ & $1.4^{\mathrm{c}}$ & 0.2 & $P<0.001$ \\
\hline Metabolizable energy (ME) (MJ/d) & $18 \cdot 4^{\mathrm{a}}$ & $54 \cdot 9^{\mathrm{b}}$ & $76 \cdot 7^{c}$ & 3.9 & $P<0.01$ \\
\hline \multicolumn{6}{|l|}{ Energy loss as: } \\
\hline faeces $\quad(M J / 100 \mathrm{MJ}$ GE intake $)$ & $55 \cdot 8^{a}$ & $40 \cdot 6^{b}$ & $30 \cdot 1^{c}$ & 1.6 & $P<0.01$ \\
\hline (MJ/100 MJ GE intake) & 3.1 & 3.6 & $4 \cdot 1$ & 0.3 & NS \\
\hline (MJ/100 MJ GE intake) & $10 \cdot 4^{\mathrm{a}}$ & $11 \cdot 4^{\mathrm{a}}$ & $6 \cdot 7^{\mathrm{b}}$ & 0.7 & $P<0.01$ \\
\hline Heat production (MJ/100 MJ GE intake) & $58 \cdot 1$ & 41.9 & $42 \cdot 3$ & 4.9 & NS \\
\hline
\end{tabular}

a,b,c Mean values within a row not sharing a common superscript letter were significantly different, $P<0.05$.

* Methane conversion rate.

of cattle fed on Angleton grass was lower $(P<0 \cdot 01)$ than for cattle fed on Rhodes grass, and both were lower $(P<0.01)$ than for cattle fed on the high-grain diet. Faecal energy loss $(\mathrm{MJ} / 100 \mathrm{MJ}$ GE intake) was highest $(P<0 \cdot 01)$ for cattle fed on Angleton grass and lowest $(P<0.01)$ for cattle fed on the high-grain diet, whereas there was no significant difference in urinary energy loss between the three different diets. $\mathrm{CH}_{4}$ energy loss (methane conversion rate (MCR); MJ/100 MJ GE intake) was not significantly different between cattle fed on Angleton grass and Rhodes grass, but it was higher $(P<0.01)$ than for cattle fed on the high-grain diet. Heat production was not significantly affected by dietary treatment, although heat production of cattle fed on Angleton grass tended $(P=0.06)$ to be higher than that of cattle fed on Rhodes grass and the high-grain diet. Cattle fed on Angleton grass had negative energy retention, which was lower $(P<$ $0 \cdot 01)$ than for cattle fed on Rhodes grass or the high-grain diet. The metabolizability (ME/GE) of the high-grain diet was higher $(P<0.001)$ than for Rhodes grass, and both were higher $(P<0.001)$ than for Angleton grass.

\section{Methane production}

Daily $\mathrm{CH}_{4}$ production (g/d) for cattle fed on Rhodes grass was higher $(P<0.01)$ than for cattle fed on both Angleton grass and the high-grain diet (Table 4$). \mathrm{CH}_{4}$ production
( $\mathrm{g} / \mathrm{kg}$ digestible organic matter intake) for cattle fed on Angleton grass (75.4 (SE 4.0)) was higher $(P<0.05)$ than for cattle fed on the Rhodes grass (64.6 (SE 1.7)), and both were higher $(P<0.05)$ than for the high-grain diet $(32.1$ (SE 3.4)). $\mathrm{CH}_{4}$ production $(\mathrm{g} / \mathrm{kg}$ live-weight gain) for cattle fed on Rhodes grass was 3.9 -fold higher $(P<0.05)$ than for cattle fed on the high-grain diet. For cattle in positive live-weight gain (i.e. Rhodes grass and high-grain diet), there was a curvilinear association between $\mathrm{CH}_{4}$ production $(\mathrm{g} / \mathrm{kg}$ liveweight gain) and live-weight gain $(r 0.96, P<0.001)$, and a linear association between $\mathrm{CH}_{4}$ production $(\mathrm{g} / \mathrm{kg}$ liveweight gain) and feed : gain ratio $(r 0.96, P<0.001)$ (Fig. 1). For the tropical forage diets (i.e. Angleton grass and Rhodes grass) $\mathrm{CH}_{4}$ production (g/d) was linearly related to DM intake $(r 0.99, P<0.001)$ (Fig. 2). For cattle fed on the high-grain diet, the relationship between DM intake $(\mathrm{kg} / \mathrm{d})$ and $\mathrm{CH}_{4}$ production $(\mathrm{g} / \mathrm{d})$ was not statistically significant $(P=0.09)$.

\section{Discussion}

This paper reports data describing $\mathrm{CH}_{4}$ production from, and energy utilization of, a range of diets fed to cattle (i.e. Brahman) in tropical regions of the world. The diets that were used included (1) a mature tropical forage with a low digestibility and low $\mathrm{N}$ content (i.e. Angleton grass), (2) an immature tropical forage with a medium digestibility and $\mathrm{N}$

Table 4. Methane production by cattle fed on Angleton grass, Rhodes grass or a high-grain diet

\begin{tabular}{|c|c|c|c|c|c|}
\hline & $\begin{array}{l}\text { Angleton grass } \\
\qquad n 6\end{array}$ & $\begin{array}{l}\text { Rhodes grass } \\
\qquad n 6\end{array}$ & $\begin{array}{l}\text { High grain } \\
\qquad n 6\end{array}$ & Pooled SE & $\begin{array}{l}\text { Statistical significance of } \\
\text { difference between means }\end{array}$ \\
\hline \multicolumn{6}{|l|}{ Methane production } \\
\hline $\mathrm{g} / \mathrm{d}$ & $113^{a}$ & $257^{b}$ & $160^{a}$ & 18 & $P<0.01$ \\
\hline $\mathrm{g} / \mathrm{kg}$ DOMI & $75 \cdot 4^{a}$ & $64 \cdot 6^{\mathrm{b}}$ & $32 \cdot 1^{c}$ & $2 \cdot 7$ & $P<0.05$ \\
\hline g/kg live-weight gain & $-{ }^{*}$ & $500 \cdot 4^{a}$ & $127 \cdot 3^{b}$ & $76 \cdot 2$ & $P<0.01$ \\
\hline
\end{tabular}

DOMI, digestible organic matter intake.

${ }_{a, b, c}$ Mean values within a row not sharing a common superscript letter were significantly different, $P<0.05$

${ }^{*}$ Not calculated, as cattle experienced live-weight loss. 


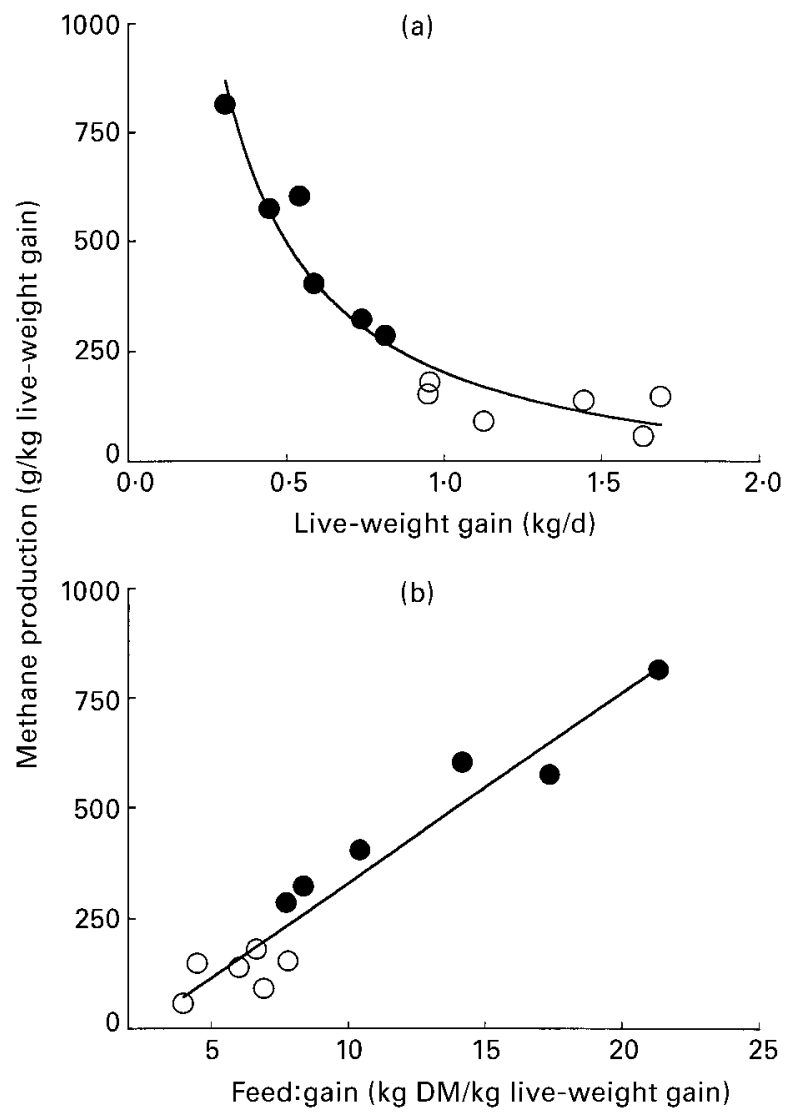

Fig. 1. The relationship between (a) live-weight gain and methane production, and (b) feed:gain ratio and methane production for cattle fed on Rhodes grass $(\bullet)$ or a high-grain diet $(O)$. For details of diets, see Table 1. Panel (a): the relationship is described by the equation $y=90.2+293.3 / x(r$ 0.96, $P<0.001)$. Panel (b): the relationship is described by the equation $y=99.9+43.1 \times(r$ 0.96, $P<0.001)$.

content (i.e. Rhodes grass), and (3) a high-grain diet with a high digestibility and $\mathrm{N}$ content. Our results indicate that for cattle fed on tropical forage diets, $\mathrm{CH}_{4}$ production was higher and energy utilization lower than published values for temperate forage diets; whereas for cattle fed on the high-grain diet, $\mathrm{CH}_{4}$ production and energy utilization were similar to published values for temperate breeds of cattle fed on high-grain diets.

$\mathrm{CH}_{4}$ production expressed as a percentage of GE intake, termed MCR by the Intergovernmental Panel on Climate Change (1996), is of critical importance for inventories of $\mathrm{CH}_{4}$ emissions of ruminant livestock because it is used in the algorithms for estimating $\mathrm{CH}_{4}$ emissions of ruminant populations (Organization for Economic Cooperation and Development, 1991; US Environmental Protection Agency, 1994; Intergovernmental Panel on Climate Change, 1996). Despite the cattle being fed on two tropical forage diets (i.e. Angleton and Rhodes grass), and having marked differences in rate of live-weight change (-0.9 (SE 0.2) and 0.6 (SE 0.1) $\mathrm{kg} / \mathrm{d}$ respectively) and in vivo digestibility (41 (SE 2)\% and 60 (SE 1) \% respectively), the MCR for Angleton grass (10.4 (SE 1.1)\%) and Rhodes grass (11.4 (SE 0.3) \%) were not significantly different. MCR for both tropical forage

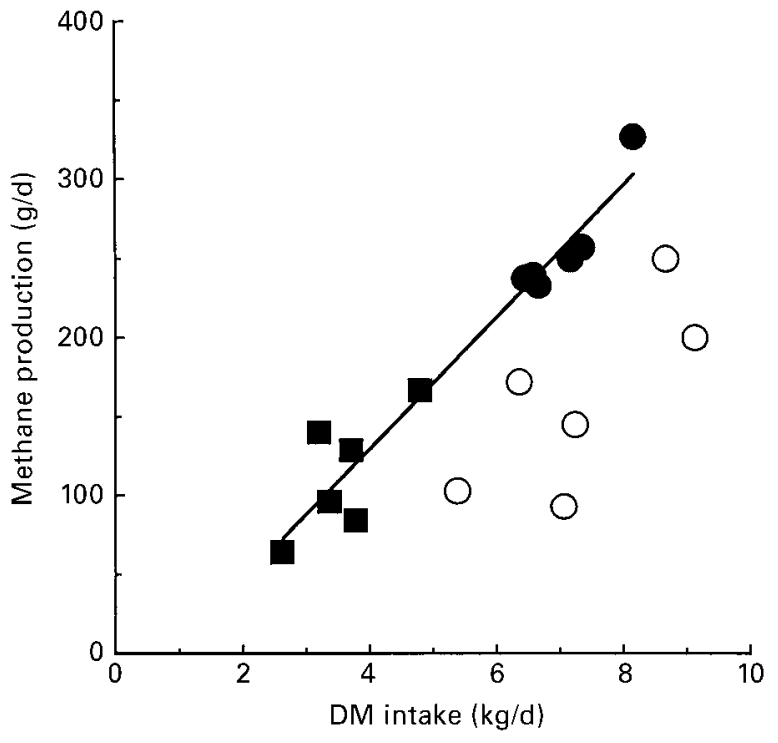

Fig. 2. The relationship between DM intake and methane production for cattle fed on tropical forage diets (Angleton grass ( $\mathbf{\square})$, Rhodes grass $(\bullet)$ ). The relationship is described by the equation $y=41.5 x-$ $36.2(r 0.99, P<0.001)$. Values for cattle fed on a high-grain diet $(O)$ are presented but were not included in the regression analysis.

diets were higher than values of 5.5-6.5\%, which are recommended for use in greenhouse gas inventories of cattle fed on temperate forage diets (US Environmental Protection Agency, 1994; Intergovernmental Panel on Climate Change, 1996; Johnson \& Ward, 1996). The higher MCR of tropical forage species is presumably related to the relatively high levels of fibre and lignin (Van Soest, 1994), low levels of non-fibre carbohydrate (Van Soest, 1994) and low digestibility (Minson, 1990) compared with temperate forage species. This observation leads us to suggest that tropical forage species may have higher MCR than temperate forage diets; however, before concluding this a wider range of tropical species should be investigated.

In a recent review, the US Environmental Protection Agency (1994) highlighted the fact that there is only one report of MCR for any ruminant species fed on a tropical forage diet. MCR of sheep offered Seteria spacelata and Digetaria decumbens were 7.3 and $6.0 \%$ respectively when fed ad libitum, and 8.9 and $8.5 \%$ respectively, when fed at a restricted level (i.e. 40-43\% of ad libitum intake) (Margen et al. 1988). However these MCR do not strictly represent a tropical forage diet, because most of the stem component of these diets was removed and discarded before the diet was offered to the sheep, thus increasing the digestibility compared with diets comprising complete plants. The low levels of ash-free NDF (i.e. total fibre) reported for these diets (63-66\%) fed to sheep (Margen et al. 1988) compared with Angleton and Rhodes grass diets in the present experiment (i.e. 72-75\%) support this conclusion. Terada et al. (1987) observed that MCR for cattle fed on a temperate forage diet (i.e. Dactylis glomerata L. (Orchard grass)) was $0.4 \%$ units higher $(P<0.05)$ than for sheep fed on the same diet. 
Table 5. Gross energy (GE) intake, methane conversion rate (MCR) and methane production in the present experiment compared with predictions using the methodology of the Intergovernmental Panel on Climate Change (IPCC) (1996) and the National Greenhouse Gas Inventory Committee (NGGIC) (1996)

\begin{tabular}{lccc}
\hline & $\begin{array}{c}\text { Angleton } \\
\text { grass }\end{array}$ & $\begin{array}{c}\text { Rhodes } \\
\text { grass }\end{array}$ & $\begin{array}{c}\text { High } \\
\text { grain }\end{array}$ \\
\hline GE intake (MJ/d) & $59 \cdot 4$ & 123.9 & $129 \cdot 8$ \\
Present experiment & - & 144.0 & $169 \cdot 0$ \\
IPCC (1996) & 88.0 & 131.4 & $153 \cdot 8$ \\
NGGIC (1996) & & & \\
MCR (\% GE intake) & $10 \cdot 4$ & 11.4 & $6 \cdot 7$ \\
Present experiment & $7 \cdot 0$ & $6 \cdot 0$ & $6 \cdot 0$ \\
IPCC (1996) & $6 \cdot 2$ & $7 \cdot 3$ & $8 \cdot 7$ \\
NGGIC (1996) & & & \\
Methane production (g/d) & 113 & 257 & 160 \\
Present experiment & - & 156 & 184 \\
IPCC (1996) & 98 & 174 & 157 \\
NGGIC (1996) & & & \\
\hline
\end{tabular}

For cattle fed on the high-grain diet, which contained 250 (SE 20) g forage/kg, MCR was 6.7 (SE 0.7) \%, which is not different from the value of $5 \cdot 5-6.5 \%$ recommended for both beef and dairy cattle fed on high-grain and temperate forage diets in developed countries (Intergovernmental Panel on Climate Change, 1996). In contrast, feedlot diets in the USA typically have a forage component of up to $100 \mathrm{~g} / \mathrm{kg}$; for these diets an MCR of $4.0 \%$ is recommended (Intergovernmental Panel on Climate Change, 1996). Furthermore, from the predictive equations of Moe \& Tyrrell (1979), which are based on data collected from dry and lactating dairy cattle fed on a range of forage and high-grain diets, the MCR of cattle fed on the high-grain diet in the present experiment was 5.1-6.2\%; and this predicted value is not different from our measured value of 6.7 (SE 0.7) \% (Table 5).

GE intake is another critically important component of the algorithms for estimating $\mathrm{CH}_{4}$ emission of livestock. The Intergovernmental Panel on Climate Change's (1996) procedure for estimating GE intake is based on the National Research Council (1984) net energy system for estimating feed requirements of ruminants. Using the Intergovernmental Panel on Climate Change (1996) methodology, we calculated for the Rhodes grass and high-grain diet, that GE intakes were overestimated by $16 \%$ and $30 \%$ respectively (Table 5). However, maintenance energy requirements of Brahman cattle are $14 \%$ lower than for Hereford $\times$ Shorthorn (B. taurus) cattle (Vercoe, 1970); if the estimates for GE intake are adjusted for this difference, intakes remain overestimated but to a lesser degree (6 and $22 \%$ respectively). In contrast to Intergovernmental Panel on Climate Change (1996) methodology, the National Greenhouse Gas Inventory Committee (1996) estimates GE intake from the product of DM intake $(\mathrm{kg} / \mathrm{d})$ and the GE value of feed (18.4 MJ/kg DM; Standing Committee on Agriculture, 1990). The predictive equations of Minson \& McDonald (1987), which are based on temperate forage data, are used by the National Greenhouse Gas Inventory Committee (1996) to predict DM feed intake of cattle fed on forage diets. Using these equations for cattle fed on Angleton grass in the present experiment, we calculated that GE intake was overestimated by $48 \%$, whereas GE intake for Rhodes grass was overestimated by only $6 \%$ (Table 5 ).

Inappropriate estimates of MCR and/or GE intake may lead to inaccurate predictions of annual $\mathrm{CH}_{4}$ emissions for cattle (kg/head per year). Our $24 \mathrm{~h}$ measurements of $\mathrm{CH}_{4}$ production for cattle fed on Rhodes grass, Angleton grass and the high-grain diet were 257 (SE 14), 113 (SE 16) and 160 (SE 24) g/d. In one case (i.e. Rhodes grass) the measured value was higher than the predicted value which we calculated using both Intergovernmental Panel on Climate Change (1996) and National Greenhouse Gas Inventory Committee (1996) methodologies (Table 5). Cattle managed in tropical environments are not fed on a uniform quality diet throughout the year, rather they consume a range of diets which differ greatly between the wet and dry seasons. Using our measurements of $\mathrm{CH}_{4}$ production $(\mathrm{g} / \mathrm{d})$ for $360 \mathrm{~kg}$ cattle (live-weight gain $0-0.3 \mathrm{~kg} / \mathrm{d}$ ) fed on a tropical forage diet (i.e. Angleton grass and Rhodes grass), we calculated that annual $\mathrm{CH}_{4}$ production is about $79 \mathrm{~kg}$ per year (range $73-84 \mathrm{~kg}$ per year). This value appears to be higher than Intergovernmental Panel on Climate Change (1996) estimates for $\mathrm{CH}_{4}$ production for cattle maintaining live weight in tropical environments (e.g. India, $41 \mathrm{~kg} / \mathrm{head}$ per year; Latin America, $58 \mathrm{~kg} / \mathrm{head}$ per year); this observation is consistent with the higher MCR for tropical forages.

$\mathrm{CH}_{4}$ production per unit of animal production (i.e. $\mathrm{g} / \mathrm{kg}$ live-weight gain) is a suitable index for comparing greenhouse gas emissions of livestock under different feeding systems. In this experiment $\mathrm{CH}_{4}$ production of cattle fed on Rhodes grass was 3.9 -fold higher $(P<0.05)$ than that in cattle fed on the high-grain diet (Table 4). The linear association between feed : gain ratio and $\mathrm{CH}_{4}$ production (Fig. 1) indicates that improving feed quality (i.e. digestibility) is one practical means of reducing $\mathrm{CH}_{4}$ production; however, the curvilinear association between live-weight gain and $\mathrm{CH}_{4}$ production (g/kg live-weight gain) suggests that $\mathrm{CH}_{4}$ production can only be reduced for cattle experiencing low live-weight gains. A similar inverse curvilinear relationship for milk production and $\mathrm{CH}_{4}$ production $\left(\mathrm{CH}_{4} / \mathrm{kg}\right.$ milk production) has been shown for dairy cattle (Kirchgeßner et al. 1995; Kurihara et al. 1997). $\mathrm{CH}_{4}$ production $(\mathrm{g} / \mathrm{kg}$ live-weight gain) for tropical cattle fed on the high-grain diet is similar to that for Japanese Black and Holstein steers (i.e. B. taurus) fed on diets of similar composition, whereas $\mathrm{CH}_{4}$ production by cattle fed on Rhodes grass in this experiment (i.e. $500 \mathrm{~g} / \mathrm{kg}$ live-weight gain) was higher than that by temperate breeds of cattle (251 $\mathrm{g} / \mathrm{kg}$ live-weight gain) with comparable live-weight gains (Kurihara et al. 1998).

For cattle fed on the two tropical forage diets investigated in this experiment, DM intake was linearly related to $\mathrm{CH}_{4}$ production (g/d) (Fig. 2). We cannot conclude that this relationship predicts $\mathrm{CH}_{4}$ production by cattle fed on other tropical forages, and suggest that a wider range of tropical forages be studied to confirm our observations. In contrast, data for cattle fed on the high-grain diet were not included in the regression analysis because the data were outside the line of best fit for the tropical forages. This observation is consistent with Moe \& Tyrrell's (1979) conclusions, that at high levels of DM intake $\mathrm{CH}_{4}$ production is more precisely predicted by including the intakes of 
individual feed components (i.e. non-fibre carbohydrate, hemicellulose and cellulose) rather than using DM intake alone. Kriss (1930) also observed a strong relationship between DM intake and $\mathrm{CH}_{4}$ production for cattle fed on temperate forages. The gradient $\left(\mathrm{g} \mathrm{CH}_{4} / \mathrm{kg} \mathrm{DM}\right.$ intake) of the relationship in Fig. 2 describing tropical forages was $2 \cdot 1$-fold higher than for the relationship describing temperate forages $\left(41.5\right.$ v. $19.5 \mathrm{~g} \mathrm{CH}_{4} / \mathrm{kg} \mathrm{DM}$ intake) (Kriss, 1930), which is further evidence that $\mathrm{CH}_{4}$ production is higher for cattle fed on tropical forages, particularly at higher levels of intake.

The major difference we observed between tropical forages studied in this experiment and published values for temperate forages was the higher MCR, which were associated with lower ME intake (MJ/d per kg live weight) and lower energy retention (MJ/100 MJ GE intake) (Table $3)$. These observations are consistent with the volume of literature indicating that DM utilization (i.e. DM digestibility) is lower for tropical than temperate forages (Minson, 1990). $\mathrm{CH}_{4}$ production is related to dietary energy partition as the former represents a reduction in available ME. The higher MCR for tropical forages in the present experiment indicate that there is potential for greatly improving $\mathrm{ME}$ availability of tropical forage diets, compared with diets fed to cattle in temperate regions of the world which have lower MCR. Improved ME availability may be achieved through the mitigation of $\mathrm{CH}_{4}$ output. We have recently demonstrated that $\mathrm{CH}_{4}$ production can be inhibited for a $28 \mathrm{~d}$ period using a novel feed additive (McCrabb et al. 1997). Using such technologies for reducing $\mathrm{CH}_{4}$ emissions over prolonged periods may lead to animal production benefits being realized in commercial production systems.

\section{Acknowledgements}

The authors are grateful to Dean Gibson, Bill van den Heuval and Bob Rabbet for their expert assistance. Mitsunori Kurihara gratefully acknowledges receipt of an Australia-Japan Exchange Fellowship from the Australian Academy of Science.

\section{References}

Blaxter KL \& Clapperton JL (1965) Prediction of the amount of methane produced by ruminants. British Journal of Nutrition 19, 511-522.

Brouwer E (1965) Report of sub-committee on constants and factors. In Proceedings of the 3rd Symposium on Energy Metabolism, pp. 441-443 [KL Blaxter, editor]. London: Academic Press.

Crutzen PJ, Aselmann I \& Seiler W (1986) Methane production by domestic animals, wild ruminants, other herbivorous fauna and humans. Tellus 38B, 271-284.

Czerkawski JW (1969) Methane production in ruminants and its significance. World Review of Nutrition and Dietetics 11, 240282.

Faichney GJ \& White GA (1983) Methods for the Analysis of Feeds Eaten by Ruminants. Melbourne: CSIRO.

Intergovernmental Panel on Climate Change (1990) Climate Change: The IPCC Scientific Assessment. Cambridge: Cambridge University Press.

Intergovernmental Panel on Climate Change (1996) Greenhouse Gas Inventory Revised Methodology. Guidelines for National Greenhouse Gas Inventories, vol. 3. Bracknell: IPCC.
Johnson DE \& Ward GM (1996) Estimates of animal methane emissions. Environmental Monitoring and Assessment 42, 133-141.

Kirchgeßner M, Windisch W \& Muller HL (1995) Nutritional factors for the quantification of methane production. In Ruminant Physiology: Digestion, Metabolism, Growth and Reproduction, pp. 333-347 [WV Engelhardt, S Leonhard-Marek, G Breves and D Giesecke, editors]. Stuttgart: Ferdinand Enke Verlag.

Kurihara M, Shibata M, Nishida T, Purnomoadi A \& Terada F (1997) Methane production and its dietary manipulation in ruminants. In Rumen Microbes and Digestive Physiology in Ruminants, pp. 199-208 [R Onodera, H Itabashi, K Ushida, H Yano and Y Sasaki, editors]. Basel: S. Karger.

Kurihara M, Terada F, Hunter RA, Nishida T \& McCrabb GJ (1998) The effect of diet and liveweight gain on methane production in temperate and tropical beef cattle. Proceedings of the 8th World Conference on Animal Production, vol. 1, pp. 364-365. Seoul: Seoul National University.

Kriss M (1930) Quantitative relations of the dry matter of the food consumed, the heat production, the gaseous outgo and the insensible loss in body weight of cattle. Journal of Agricultural Research 40, 283.

McCrabb GJ, Berger KT, Magner T, May C \& Hunter RA (1997) Inhibiting methane production in Brahman cattle by dietary supplementation with a novel compound and the effects on growth. Australian Journal of Agricultural Research 48, 323-329.

Magner T, Sim WD \& Bardsley DH (1988) Apparatus for urine collection from female cattle in metabolism crates. Australian Journal of Experimental Agriculture 28, 725-727.

Margen DE, Graham N McC, Minson DJ \& Searle TW (1988) Energy and protein values of four forages, including a comparison between tropical and temperate species. Australian Journal of Experimental Agriculture 28, 729-736.

Minson DJ (1990) Forage in Ruminant Nutrition. New York, NY: Academic Press.

Minson DJ \& McDonald CK (1987) Estimating forage intake from the growth of beef cattle. Tropical Grasslands 21, 116122.

Moe PW \& Tyrrell HF (1979) Methane production by dairy cows. Journal of Dairy Science 62, 1583-1586.

National Greenhouse Gas Inventory Committee (1996) Australian Methodology for the Estimation of Greenhouse Gas Emissions and Sinks. Workbook for Livestock, Workbook 6.1. Canberra: Department of Environment, Sport and Territories.

National Research Council (1984) Nutrient Requirements of Beef Cattle. Washington, DC: National Academy Press.

Organization for Economic Cooperation and Development (1991) Estimation of Greenhouse Gas Emissions and Sinks. Final Report from OECD Experts Meeting, 18-21 February 1991, Paris, France. Prepared for the Intergovernmental Panel on Climate Change. Paris: OECD.

Shibata M, Terada F, Kurihara M, Nishida T \& Iwasaki K (1993) Estimation of methane production in ruminants. Animal Science and Technology (Japan) 64, 790-796.

Standing Committee on Agriculture (1990) Feeding Standards for Australian Livestock, Ruminants. Melbourne: CSIRO.

Terada FK, Iwasaki R, Tano R \& Kameoka K (1987) Comparison of metabolizability and metabolizable energy contents among cattle, sheep and goats fed the same diets. In Energy Metabolism of Farm Animals. European Association for Animal Production (EAAP) Publication no. 32, pp. 130-133 [PW Moe, editor]. Rome: EAAP.

Turner HG \& Thornton RF (1966) A respiration chamber for cattle. Proceedings of the Australian Society of Animal Production 6, 413-419.

US Environmental Protection Agency (1994) International Anthropogenic Methane Emissions: Estimates for 1990. EPA 
230-R-93-010. Washington, DC: Office of Policy, Planning and Evaluation, US EPA.

Van Soest PJ (1994) Nutritional Ecology of the Ruminant, 2nd ed. Ithaca, NY: Cornell University Press.

Van Soest PJ, Robertson JB \& Lewis BA (1991) Methods for dietary fiber, neutral detergent fiber, and nonstarch polysaccharides in relation to animal nutrition. Journal of Dairy Science 74, 35833597.
Vercoe JE (1970) The fasting metabolism of Brahman, Africander and Hereford $\times$ Shorthorn cattle. British Journal of Nutrition 24, 599-606.

Williams CH \& Twine JR (1967) Determination of Nitrogen, Sulphur, Phosphorus, Potassium, Sodium, Calcium and Magnesium in Plant Material by Automatic Analysis. CSIRO Division of Plant Industries Technical Paper no. 24. Canberra: CSIRO Division of Plant Industry. 